\title{
Meningo-Ependymitis in Whipple's Disease
}

\author{
L. R. LAPOINTE, J. LAMARCHE, A. SALLOUM and R. BEAUDRY
}

SUMMARY: Six years after apparent complete recovery from intestinal Whipple's disease, a 56 year old man developed insidious progressive somnolence and gait ataxia. Studies showed hydrocephalus with obstruction of the aqueduct and CSF leukocytosis and elevated protein. Arachnoid biopsy during craniolomy revealed chronic inflammatory infiltration with PAS-positive macrophages. The patient died 5 years later despite two courses of antibiotic therapy. This is the first report of histologically confirmed cerebral Whip-

RESUME: Un homme de 50 ans dont la maladie de Whipple intestinale était guérie depuis 6 ans, développa une somnolence et une ataxie à la démarche de progression insidieuse. Des études ont montré une hydrocéphalie avec obstruction de l'aque. duc ainsi qu'une leucocytose et une augmentation des protéines dans le LCR. Lors d'une craniotomie une biopsie arachnoidienne montra une infiltration inflammatoire chronique par des macrophages positifs au PAS. Le patient est décédé 5 ans plus tard malgré deux séries de traitements aux antibiotiques. Le présent rapport est la première confirmation histo- ple's disease during life.

Whipple's disease is a systemic infectious disorder. Cerebral involvement even in neurologically asymptomatic patients should be sought with periodic CSF cytologic studies and a search for hydrocephalus. The possibility of cerebral Whipple's disease should be considered in the presence of unexplained hydrocephalus and/or chronic inflammatory changes in the spinal fluid, especially in those with past or active intestinal disease.

logique régionale de la maladie de Whipple cérébrale.

La maladie de Whipple est un désordre infectieux systémique. On devrait toujours rechercher l'implication cérébrale chez les patients neurologiquement asymptomatiques en obtenant périodiquement des cytologies du LCR et en recherchant l'hydrocéphalie. La possibilité de maladie de Whipple devrait toujours être considérée chez des patients présentant des signes neurologiques inattendus tels l'hydrocéphalie et les modifications inflammatoires du LCR, surtout chez ceux qui ont une histoire de troubles intestinaux.
From the Departments of Medicine and Pathology, Centre Hospitalier Universitaire de Sherbrooke. Sherbrooke, P.Q.

Presented at the 11 th World Congress of Neurology Amsterdam, September 23, 1977.

Reprint requests to: Dr. L.R. Lapointe at the Section of Neurology, Department of Medicine, Centre Hospitalier Universitaire de Sherbrooke, Sherbrooke, Québec, JIH SN4, Canada.

\section{INTRODUCTION}

Whipple's disease was first described as an intestinal lipodystrophy with manifestations related principally to intestinal malabsorption. It was thought to be due to either an intrinsic mucosal disorder of fat metabolism or to enteric lymphatic obstruction. The disease, which responds to antibiotic therapy, is now known to be a disseminated systemic infection (Clancy et al., 1975; Maizel et al., 1970). Possible involvement of the nervous system is not widely appreciated (Enzinger \& Holwig, 1963). The literature contains post-mortem observations of central nervous Whipple's disease in twentyone cases and more recent presumptive diagnosis in nine living patients with post-mortem confirmation in two. The case of a patient is reported with a diagnosis of central nervous system Whipple's disease, confirmed by meningeal biopsy, and post-mortem studies several years later.

\section{CASE REPORT}

A 56 year-old carpenter was hospitalized in March of 1971, six years after successful tetracycline therapy of biopsy-confirmed enteric Whipple's disease, because of somnolence and gait instability. The illness had been of insidious onset with progression over the previous half-year. Physical examination showed a lethargic man with a left parasternal heart murmur not noted six years earlier, as well as relatively mild dementia and moderate dyspraxia of upper limbs and gait. There were also primitive sucking and bilateral grasp reflexes together with generalized tendon hyperreflexia. Plantar reflexes were flexor. Ventriculography demonstrated obstructive hydrocephalus excluding the fourth ventricule, and iodoventriculography revealed saccular dilatation of the 
rostral portion of the aqueduct with obstruction below (figure 1). Spinal fluid drawn before invasive studies showed normal glucose concentration, but $104 \mathrm{mg} / 100 \mathrm{cc}$ of protein with 33 lymphocytes and 3 red blood cells/ $\mathrm{cmm}$. Subsequent spinal and ventricular fluid samples were consistenly clear with normal glucose, elevated protein, and variable mild lymphocytosis. Stains and cultures for bacteria and fungi were normal. Postcentrifugal cytological examination of one sample showed no atypical cells nor any PAS-positive material free in CSF or within histiocytes. Posterior fossa craniotomy revealed granular texture and yellow discoloration of the meninges and of the fourth ventricular ependyma. Interventriculostomy was effected, together with arachnoild biopsy. After initiation of antibiotic therapy with tetracycline, a ventriculoatrial shunt was installed. Per-oral jejunal biopsy was obtained for comparison with the arachnoid, and the intestinal biopsy taken six years earlier. The arachnoid showed histological changes similar to the previous intestinal biopsy which was typical of Whipple's disease. It consisted of infiltration with macrophages filled with PAS-positive material. Recent jejunal

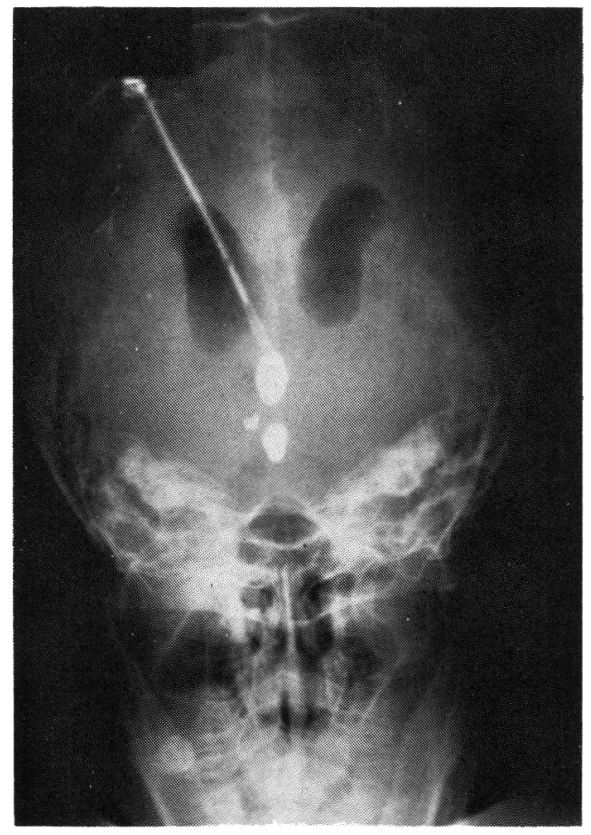

Figure 1 - Pneumo-iodoventriculography demonstrating obstructive hydrocephalus with saccular dilatation of the rostral portion of the aqueduct

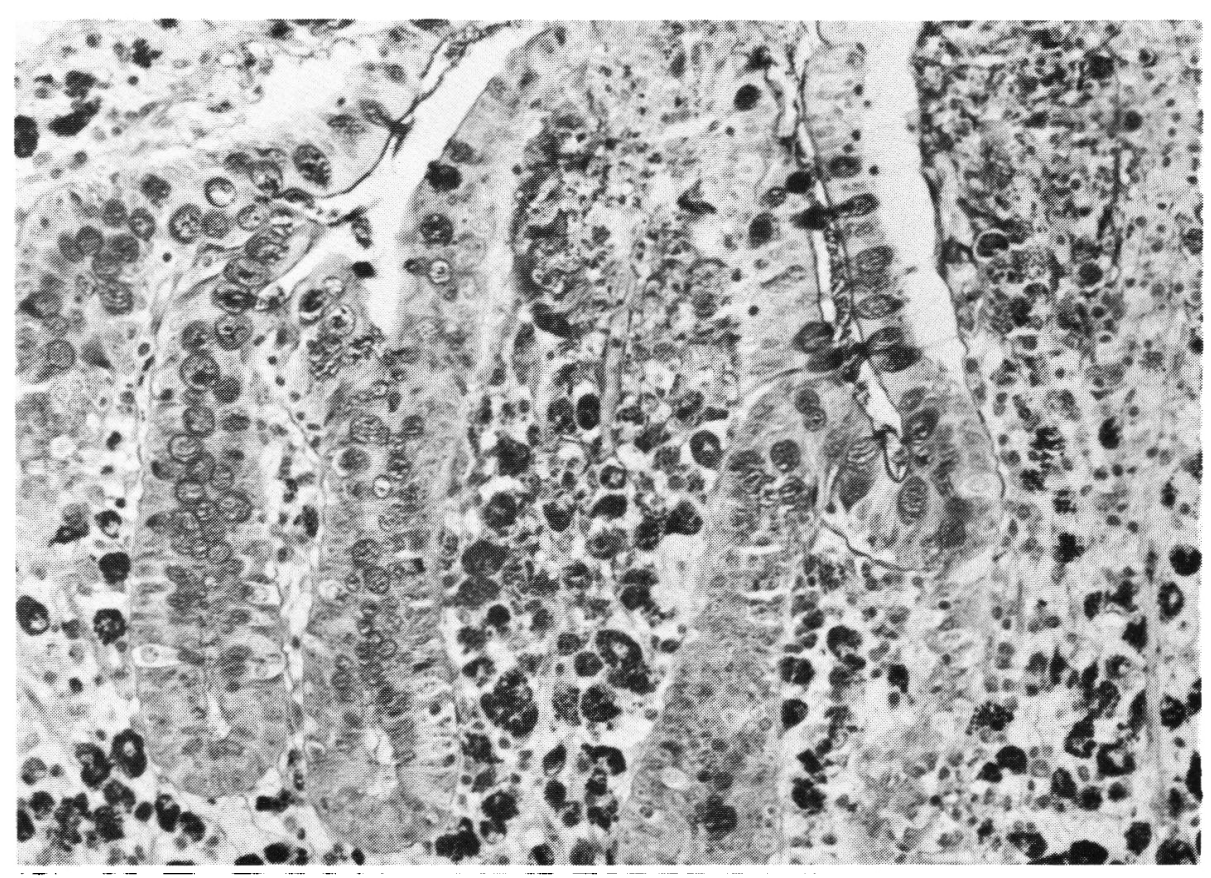

Figure $2 A-$ Jejunal biopsy in 1965. Note the presence of numerous PAS-positive macrophages in the lamina propria. (PAS stain $x 160$ )

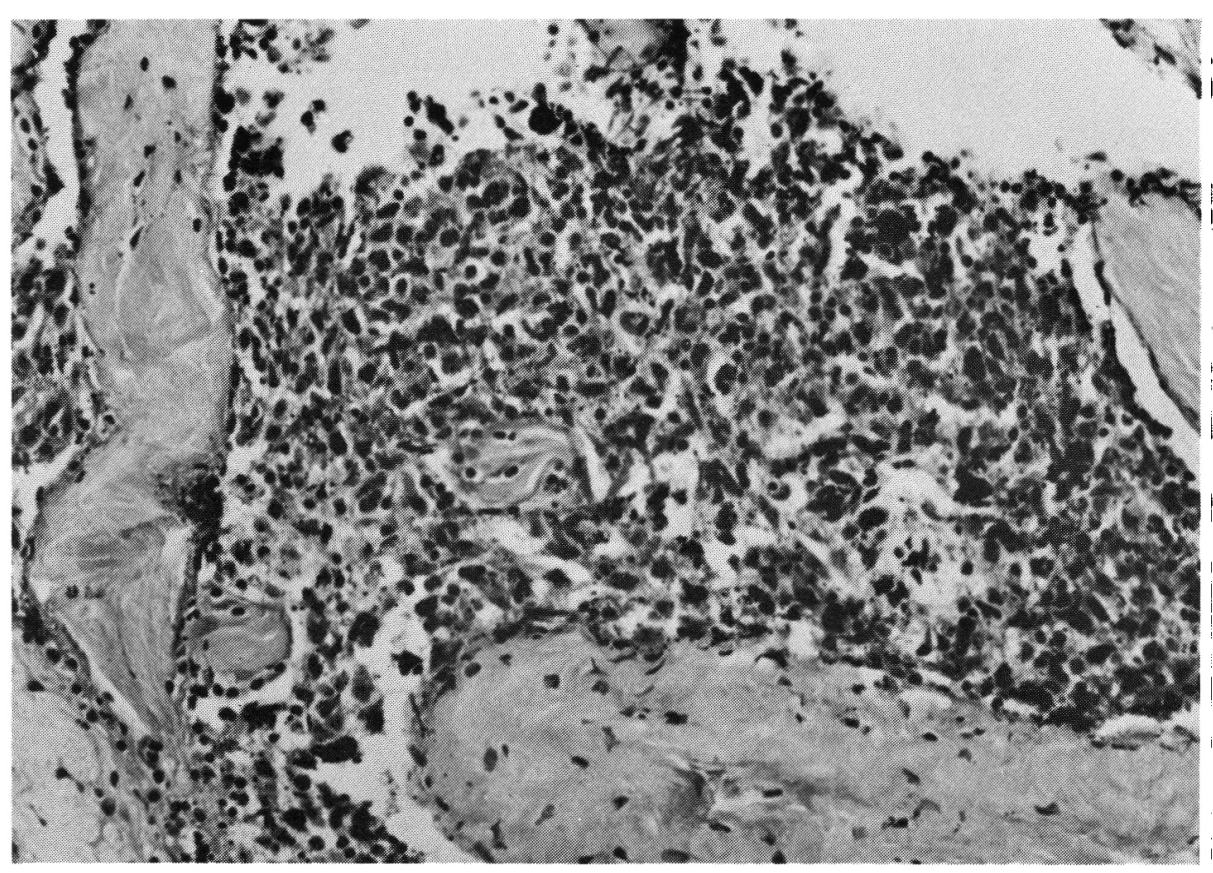

Figure 2B - Jejunal biopsy in March 1971. Note the disappearance of PAS-positive macrophages in the lamina propria. (PAS stain $\times 160$ ) 


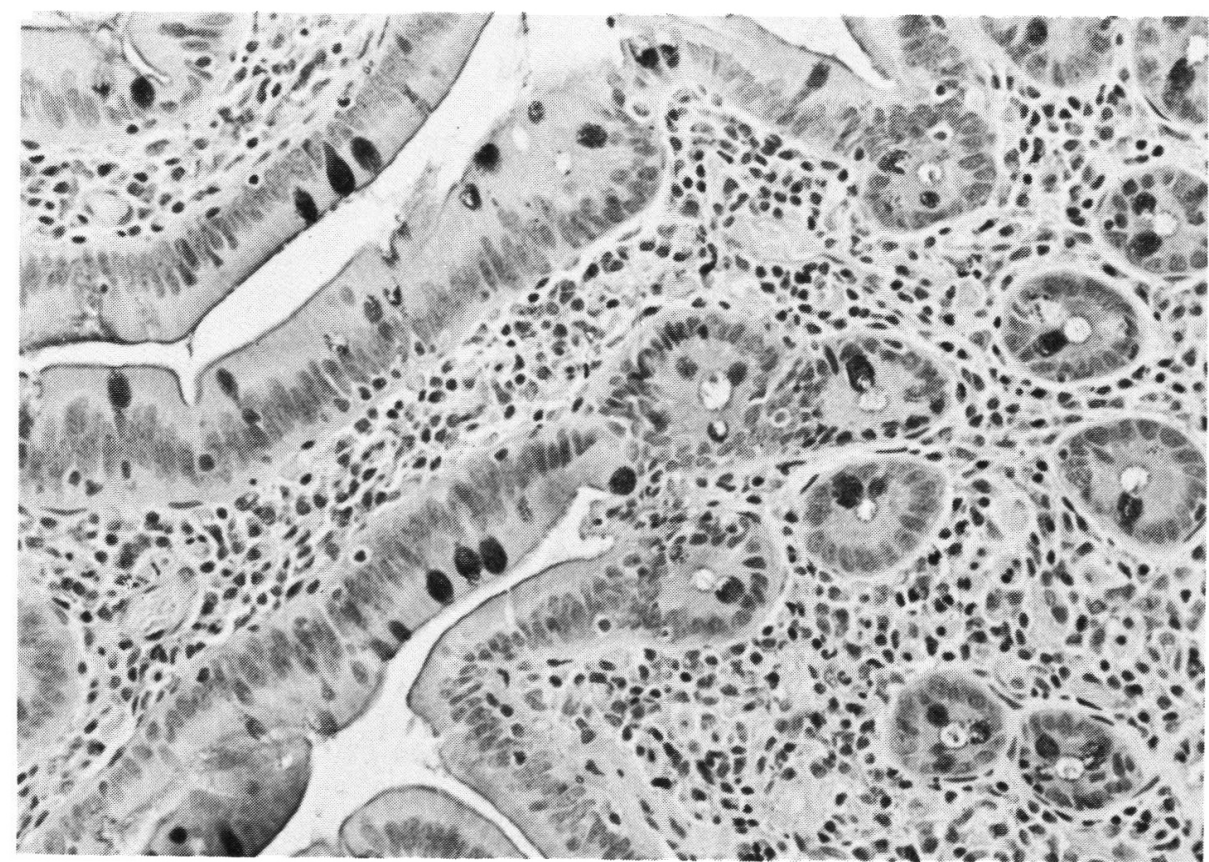

Figure 2C - Arachnoid biopsy in March 1971. Note the fibrosis and the large quantity of PAS-positive material free or within macrophages. (PAS stain $x 160$ )

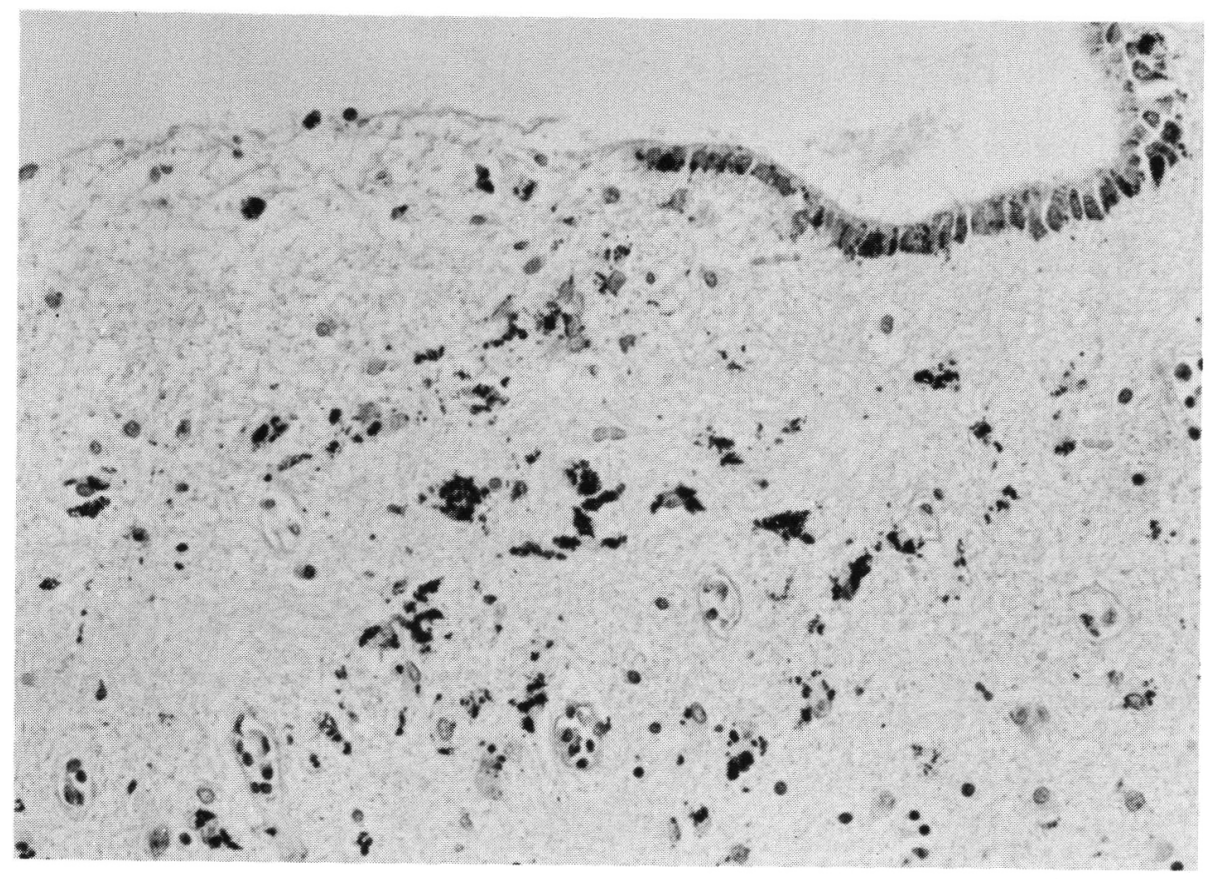

Figure 3 - Paraventricular cerebral tissue at autopsy. Note the granular ependymitis. PAS-positive material is present within ependymal cells and macrophages, and lies free in the nervous tissue. There is also a mild chronic inflammatory infiltrate in the perivascular spaces. (PAS stain $\times 160$ ) biopsy however, was normal (figure 2).

The patient was discharged moderately improved after surgical correction of hydrocephalus and long-term antibiotic therapy with tetracycline 750 $\mathrm{mg} /$ day. He was re-admitted six months later because of increasing somnolence. Spinal fluid on this occasion showed normal glucose with 108 $\mathrm{mg} / 100 \mathrm{cc}$ of protein and 10 lymphocytes/cubic $\mathrm{mm}$. Spinal fluid stains, culture, and cytology were again negative. He received more aggressive antibiotic therapy with daily intravenous penicillin 20 million units and intramuscular streptomycin $500 \mathrm{mgs}$ for two weeks, and was discharged on oral tetracycline, one gram daily, for a proposed year. There was little clinical improvement. He was admitted on two successive occasions four years later because of water-intoxication and died in June of 1976, eleven years after clinical onset of enteric Whipple's disease, and nearly six years after the first signs of central nervous system involvement.

Autopsy showed aortic stenosis and marantic endocarditis with no histological evidence of Whipple's disease outside the nervous system. Section of the brain revealed diffuse nodular irregularity of the ependyma and microscopy showed marked granular ependymitis with ependymal rosettes, gliosis, and chronic perivascular infiltration. Major accumulation of PASpositive material was apparent in ependymal cells, macrophages, and free in adjacent sub-ependymal glial tissue and perivascular cerebrum (figure 3 ).

\section{DISCUSSION}

In 1907 Whipple reported intestinal lipodystrophy in a 38 year-old medical missionary with steatorrhea, weight loss, and polyarthralgia. Cases reported in the past two decades have been found to suffer systemic disease with involvement of nearly all tissues in addition to intestine and joints (Enzinger \& Holwig, 1963). Fever, leukocytosis and a favorable response of the intestinal disease to tetracycline are compatible with a bacterial etiology. Intestinal biopsy before treatment consistently demonstrates PASpositive material in affected tissues. 
Electron microscopy has reinforced the hypothesis of bacterial etiology by demonstrating that this material consists of accumulated bacilliforme structures within sickleforme-particlecontaining (SPC) cells (Chears and Ashworth, 1961; Yardley and Hendrix, 1961). Sieraki et al (1960) drew attention to the systemic nature of the disease. They documented clinically unanticipated post-mortem histological evidence of cerebral involvement in two patients with Whipple's disease. Similar observations at autopsy have been reported in eighteen patients with late undiagnosed central nervous system disease. (Badenoch et al., 1963; De Groodt-Lasseel and Martin, 1969; Hecker and Reid, 1963; Kitamura, 1975; Koudouris et al., 1963; Kadousek and Kojecky, 1971; Lampert et al., 1962; Minauf and Stochdorph, 1969; Schochet and Lampert, 1969; Schwartzova et al., 1967; Silbert et al., 1976; Smith et al., 1965; Stoupel et al., 1969; Switz et al., 1969). A single case of the disease limited to the nervous system has been identified at autopsy (Romanul et al., 1977).

There have been four publications of nine living patients, six with confirmed previous systemic Whipple's disease. All had cerebral disease presumably of the same etiology (Feurle et al., 1979; Finelli et al., 1977; Knox et al., 1976; Masson et al., 1976). Retrospective study of intestinal $x$ rays of one patient without intestinal biopsy (Knox et al., 1976) was compatible with past enteric Whipple's disease. Finelli's two patients had no history of Whipple's disease and presented with subacute disseminated disease including the nervous system. Two cases came to autopsy and the diagnosis was confirmed in both by PAS-positive SPC cells in the brain (Feurle et al., 1979; Finelli et al., 1977).

Six of the living patients reported before our own also developed progressive central nervous system disease more than one year after apparently initial successful antibiotic therapy. Of the nine patients with active neurological disease including ophthalmoplegia only four had systemic Whipple's disease documented by intestinal biopsy. Three of these showed similar pathology and inguinal pathology in axillary and inguinal lymph nodes. Conversely, five showed neither non-neurological clinical manifestations of systemic disease nor evidence of it in intestinal biopsy. Cerebral biopsy in the few who were examined was unproductive. Three patients had PAS-positive SPC cells in cerebrospinal fluid. Two of these had normal jejunal biopsies (Finelli et al., 1977; Knox et al., 1976).

The diagnosis of central nervous system Whipple's disease is elusive because it seldom coincides with the systemic onset or exacerbation, but is most frequent in patients with systemic remission after antibiotic treatment. While clinical information has been often incomplete in the twenty-one cases discovered at autopsy, and neuropathological confirmation was lacking in seven of the nine with antemortem diagnosis, review of these plus our case reveals the major features of potential diagnostic importance shared by the majority.

- Cerebral involvement is not isolated, but a local manifestation of systemic Whipple's disease including intestinal involvement some time in its prolonged course.

- It is latent, with clinical onset between one and five years after initial diagnosis, with or without exacerbation of intestinal and systemic disease.

- It is not prevented by prolonged antibiotic therapy of the disease with standard medication including tetracycline.

- Pathologically confirmed cases show variable ventricular dilatation and chronic granular ependymitis with PAS-positive material in SPC ependymal cells and macrophages, and in periventricular cerebral tissue.

- Clinical features of periventricular encephalitis include ophthalmoplegia, myoclonus, dementia and ataxia. Patients may also show somnolence and hypothalamic neuroendocrine dysfunction with waterintoxication.

- Other manifestations include hydrocephalus and abnormal cerebrospinal fluid with elevated protein, monocytosis, and PAS-positive SPC cells in spinal fluid in a significant proportion of patients.
Results of treatment with antibiotics in late central nervous system Whipple's disease are uncertain, with only partial improvement in three of those reported. Evolution in our patient who showed some initial improvement like Feurle's patient (1979) suggests that prognosis is poor. Early diagnosis is important because of resistance to antibiotic therapy. For this reason cerebral involvement in neurologically assymptomatic patients with Whipple's disease should be sought repeatedly with spinal fluid studies and a search for hydrocephalus. Finally, the possibility of Whipple's disease and the study of spinal fluid for SPC cells together with biopsy of intestine and other tissues should be considered in patients with unexplained neurological disease including ophthalmoplegia, hydrocephalus and chronic meningitic changes in the spinal fluid especially in those with past or active intestinal disease.

\section{REFERENCES}

BADENOCH, J., RICHARDS, W.C.D. and OPPENHEIMER, D. R. (1963) Encephalopathy in a case of Whipple's Disease. $J$. Neurol. Neurosurg. Psychiat. 26: 203-210.

CHEARS, W.C. JR. and ASHWORTH, C.T. (1961). Electron Microscopic Study of the Intestinal Mucosa in Whipple's Disease. Demonstration of Encapsulated Baccilliforme Bodies in the Lesion. Gastroent. 41: 129-138.

CLANCY, R.L., TOMKINS, W.A.F. MUCKLE, T.J., RICHARDSON, H. and RAWLS, N. E., (1975). Isolation and Characterization of an aetiological Agent in Whipple's Disease. Br. Med. J. 3: 563-570.

DE GROODT-LASSELL, M. and MARTIN, J.J. (1969). L'étude ultrastructurelle des lésions du système nerveux central dans la maladie de Whipple. Pathol. Biol. 17: 121131.

ENZINGER, F. M. and HOLWIG, E. B. (1963): Whipple's Disease. Virch. Arch. Path. Anat. 366: 238-269.

FEURLE, G. E., VOLK, B. and WALDHERR, R. (1979). Cerebral Whipple's Disease with Negative Jejunal Histology. N.E. J.M., 300: 907-908.

FINELLI, P.F., McENTEE, W. V., LESSELL, S., MORGAN, T.F. and COPETTO, J. (1977). Whipple's Disease with Predominantly Neuroophthalmic Manifestations. Ann. Neurol. 1: 247-252.

HECKER, R, and REID, R.T. (1963). Cerebral Demyelination in Whipple's Disease. Med. J. Aust. 49: 211-212.

KITAMURA, T. (1975). Brain Involvement in Whipple's Disease. A Case Report. Acta Neuropath. (Berl.) 33: 275-278.

KNOX, D. L., BAYLESS, T.M. and PITTMAN, 
F. E. (1976). Neurologic Disease in Patients with Treated Whipple's Disease. Medicine 55: 467. 476.

KOUDOURIS, S. D., STERN, T.N. and UTTERBACK, R.A. (1963). Involvement of Central Nervous System in Whipple's Disease. Neurolo8y, 13: 397-404.

KOUDOUSEK, R. and KOJECKY, Z. (1971) On the Basis of Cerebral Lesions in Whipple's Disease: Rev. Czech. Med. 17: 137-142.

LAMPERT, P., TOM, M.B. and CUMMINGS, J.N. (1962). Encephalopathy in Whipple's Disease. Neurology, 12: 65-71.

MAIZEL, H., RUFFIN, J.M. and DOBBINS, W. O. (1970). Whipple's Disease: a Review of 19 Patients from one Hospital and a Review of the Literature since 1950. Medicine 49: 175-205.

MASSON, R., BOULLIAT, G. and CLAVEL, M. (1976). Une observation d'encéphalopathie myoclonique au cours de la maladie de Whipple. Rev. Neurol. (Paris) 132: 415-418.
MINAUF, M. and STOCHDORPH, O. (1969). Das ZNS Bei Morbus Whipple. Arch. Psychiat. R. Nervenkr, 212: 180-199.

ROMANUL, F.C.A., RADVANY, J. and ROSALES, R.K. (1977). Whipple's Disease confined to the brain: a Case Studied Clinically and Pathologically. J. Neurol. Neurosurg. 40: 901-909.

SCHOCHET, S.S. Jr. and LAMPERT, P.W. (1969). Granulomatous Encephalitis in Whipple's Disease. Acta Neuropath. (Berl) 13: 1-11.

SCHWARTZOVA, K., SCHWARTZ, A. and MAREK, J., (1967). Whipplova Choroba S Neurologickou Symptomatologii. Plzen. Lek. Sborn. 28: 99-106.

SIERAKI, J.C., FINE, G., HORN, R.C. JR. and BEBIN, J. (1960). Central Nervous Involvement in Whipple's Disease. J. Neuropath. Exp. Neurol. 19: 70-75.

SILBERT, S. W., PARKER, E. and HORENSTEIN, S. (1976). Whipple's Disease of the
Central Nervous System. Acta Neuropath. (Berl) 36: 31-38.

SMITH, W.T., FRENCH, J.M., GOTTSMAN, M., SMITH, A.J. and WAKESMILLER, J. A. (1965). Cerebral Complications of Whipple's Disease. Brain 88: 137-150.

STOUPEL, N., MONSEU, G. PARDOE, A., HEIMAN, R. and MARTIN, J.J. (1969) Encephalitis with myoclonus in Whipple's Disease. J. Neurol. Neurosurg. Psychiat. 32: 338343.

SWITZ, D.M., CASEY, T.R. and BOGARY, G.V. (1969). Whipple's Disease, and Papilledema. Arch. Int. Med. 123: 74-77.

YARDLEY, J.H. and HENDRIX, T.R. (1961). Combined Electron and Light Microscopy in Whipple's Disease. Demonstration of "Bacillary Bodies" in the Intestine. Bul. John Hopk. Hosp. 109: 30-98. 